\title{
The Commercial Use of Drones in U.S. National Parks
}

\author{
Johnny Elie Chamata \\ Faculty of Business, Curtin University Malaysia \\ CDT 250, Miri, Sarawak 98009 \\ email: johnny.chamata@gmail.com
}

Lisa Marie King

\begin{abstract}
Motivated by current reports showing potential socioeconomic benefits, this research investigated the use of civil drones in national parks and discussed the implications of this use, taking the United States as an example. Relying on literature about concessions in national parks, we have discussed several historical, conceptual, and legal aspects of concessions. In addition, the paper discusses the concerns of several stakeholders including the parks' management and visitors about privacy and safety. Research findings show that establishing various concession ideas in national parks is profitable and will contribute to increasing the revenues of tourism sector as well as to job creation. The research also shows that the ideas are relatively safe, and should not raise any concerns about using drones in national parks, especially when our recommendations are followed. Research limitations and future research recommendations are discussed at the end of paper.
\end{abstract}

Keywords: civil drones, national parks, concessions, concerns, commercial use.

\section{Introduction}

Civil drones were first tested in the 1970s under a project on a flying solar-powered aircraft ${ }^{1}$. Today, these aircraft are being employed in huge numbers of applications such as telecommunications, agriculture, conservation, disaster management, and law enforcement ${ }^{35}$. Civil drones can be of benefit to the society, they are capable of delivering food ${ }^{36}$, couriers $^{37}$, life jackets ${ }^{38}$, and even instructions to rescue people in critical health condition $^{39}$.

Civil drones, if deployed widely, are also capable of boosting the economy. In the United States, for instance, they are predicted to generate hundreds of thousands of jobs and some multibillion dollars ${ }^{40-43}$ before the end of 2017. In Europe, hopes are put on the civil drone industry assist in achieving the 2020 economic plans. Reports predict the generation of 150,000 jobs and yearly profits of $€ 15$ billion $^{44}$ by 2050 .
In line with these socioeconomic advantages, we attempt to present a practical example of how drones may be useful in one of the several commercial applications: tourism. We specifically address the employment of drones commercially in U.S. national parks. Thus, we herein pose the question: 'how can drones be employed in a manner that generates profit in U.S. national parks?'. We propose that the development of concessions would be profit generating, especially when the concessioners abide by our recommendations, and hence attempt reducing concerns of various stakeholders about drone flights.

Thus, the paper aims at proposing a practical example of using drones in national parks. We take the U.S. as our example, however, our findings may be perpetuated to other countries. The paper will begin with presenting a background of U.S. concessions' history, concept, contract, and regulations. Additionally, it discusses the concerns of different stakeholders towards drone flight within the parks. Finally, the paper presents 
two potential ideas for concessions which the authors believe can be profit-generating.

This study is mainly of practical significance. In line with current constantly increasing drone commercial movement, it proposes ideas for employing drones to generate profit for the tourism sector. Such effort encourages the suggestion of further ideas in the future which may contribute to the income from tourism activities and subsequently to the overall GDP. These drone businesses will not only generate additional revenues for the national park service, but create jobs and further enhance the visitor on-site experience. The paper also contributes to the growing body of knowledge on drone application in various fields. Whereas this paper does not propose a theoretical model, further future development on the research topic is desirable.

\section{The U.S. National Park Service}

In 1872, U.S. President Grant made Yellowstone the world's first national park. More parks soon followed but it wasn't until 1916 when President Wilson signed the Organic Act and founded the NPS under the Department of Interior to protect the lands, waters, and historical sites within the U.S. national parks that it truly became a nationally managed system of properties ${ }^{2}$.

In 2013, almost 274 million domestic and foreign tourists visited the U.S. National Park System ${ }^{3}$. The NPS governs over 84 million acres ${ }^{4}$ comprising hundreds of concessions $^{5}$ that provide visitors with food and beverages, trip necessities such as maps and umbrellas; fitness, sports and educational services, and music sales and performance ${ }^{6}$. At appropriate sites, park concessions also provide accommodation, transportation, and other services as well ${ }^{5}$.

The NPS manages more than 400 parks spread all over the U.S. and its territories ${ }^{7}$ with a mission to:

"preserve unimpaired the natural and cultural

resources and values of the national park system

for the enjoyment, education, and inspiration of

this and future generations ${ }^{8}$.

The NPS is also responsible for the creation and maintenance of recreational opportunities within its estate $^{8}$ including rock-climbing, snorkeling, hiking, orienteering, hiking, horse-riding, rafting, spelunking, paddling, fishing, sand-boarding, camping and wildlife viewing.

\section{Overview of NPS Concessions}

NPS provides those who are interested with opportunities to contract concessions and serve visitors on the condition that they meet park mandates ${ }^{9}$. In the latest Beyond Leopold report (2012), NPS was advised to prepare its resources for continuous changes that might occur to conserve ecological diversity and cultural and historical authenticity as well as to constantly provide park visitors with inspirational experiences ${ }^{10}$. To do so, NPS contracts with foreign and domestic companies, requiring their compliance with its regulations to avoid cancellation of their concessions ${ }^{11}$.

NPS concessions play a vital role in local economies. Residents and tourists from around the world spend dollars on different activities and facilities provided by these concessions, not to forget the thousands of jobs created $^{12}$. In 2008, NPS concessioners made a gross profit of over $\$ 1.025$ billion $^{13}$. In 2013, park visitors spent approximately $\$ 14.6$ billion on accommodation, camping, dining, groceries, and others ${ }^{14}$ injecting $1.1 \%$ or $\$ 1.3$ trillion into the tourism economy of the United States ${ }^{15}$.

\subsection{The Concession Concept}

A concession is a contract between a government or controlling body and a business entity that grants exclusive rights to conduct business operations within the former's authorities and conditions, in return for agreed ongoing fees ${ }^{16}$. The tourism concession process is concerned with three aspects: legal frameworks, business opportunities and contracts management ${ }^{17}$.

Following NPS regulations, a typical concession allows an individual or a private entity to run tourism activities in a national park. Concessioners are allowed to occupy and trade the land within a set of financial, legal, environmental, and social criteria ${ }^{18}$.

These concessions when well-planned and managed acquire the potential to hugely empower local communities through the creation of diversified job opportunities, enhancing knowledge and competences and reducing economic risks of unemployment and poverty ${ }^{19}$. In many occasions, national park concessions are perceived as contributors to the park's conservation and management plans. As park authorities usually lack funds and human resources, the intent of granting concessions is to produce surplus returns to better 
support protected areas ${ }^{17}$ and conserve the biodiversity contained within these properties ${ }^{18,19}$.

\subsection{The Contract}

A concession contract is one of several types of agreements available for entrepreneurs willing to engage in business activities in national parks. Cooperative agreements are used to guide joint federal and nongovernmental efforts and act as tools for pilot programs and testing new partnerships. Special use permits provide short-term rights for private activities on parks such as weddings, family reunions and other events. Term-limited private occupancy agreements are used to include a privately-owned land to an expanding park unit $^{20}$. Commercial use authorizations are 2-years agreements that grant limited rights to run commercial activities within parks' regulations and minimal impact on resources and values ${ }^{21}$. Concession contracts also fall into this agreement category.

The Secretary of Interior shall grant concession rights to companies or individuals based on predetermined criteria. These criteria are quite similar to a bidding process. The selection of best proposal starts with setting competitive selection conditions for different types of concessions. A public solicitation is then advertised followed by a prospectus that contains the minimum requirements for potential concessioners ${ }^{22}$.

The contract embodies privileges, permits and leases granted to a concessioner as well as liabilities ${ }^{23}$, and it is categorized according to whether the concessioner requires to be assigned a land or not ${ }^{24}$. It also covers areas concerned with fostering units' profits. A concessioner shall agree on conceptual matters such as preservation of park's property, equality of rights and obligations and abiding by the rules throughout concession's lifetime. Furthermore, contracts ensure that concessioners are technically and financially qualified and that they will comply with the park's values of preserving environmental resources and the empowerment of local community ${ }^{18}$. The term of a concession contract is usually up to 10 years; however, the NPS Director may award a term of 20 years if they determine that the contract's terms and conditions, including the required construction of capital improvements, warrant a longer term ${ }^{22}$.

Contracts are also concerned with the design and maintenance of facilities provided to concessioners ${ }^{21}$ as well as the fees they are responsible of ${ }^{19}$ such as the franchise, park entrance, and concession activity fees ${ }^{25}$. Business operations and management practices are detailed in a concession contract including operational, financial and risk mitigation plans. Farther, agreements may also include employment policies to reinforce integrity. For instance, NPS people or their relatives are not allowed to own a concession or to be employed by one $^{21}$.

\subsection{Concession Regulations}

Rules that govern concessions have changed over the course of 143 years under different NPS administration $^{26}$. In April 2000, with a delegation from the Secretary of Interior, the NPS developed their most current set of concession regulations ${ }^{23}$. These regulations concern short-term, long-term, non-profit, and temporary concessions ${ }^{27}$.

The number, location and size of a concession is assigned by local park authorities. The management also ensures concessioners will provide significant, proper, and affordable services and facilities. All concessions must work harmoniously with the park's mission and objectives, operate within its boundaries, and comply with the management's concerns about conservation and safety. Prior to contract award, concessioners must complete a market feasibility study to ensure all contract terms are satisfied ${ }^{21}$.

Regulations also cover public and recreational use of park resources such as boating and water use activities, vehicles and traffic safety, commercial and private operations, the maintenance and protection of archeological sites, minerals management, the protection and repatriation of cemetery and native Indian graves and many others ${ }^{34}$.

\section{Stakeholders' concerns}

Civil drones are very capable aircraft which are useful for humans and for businesses. Their small size allows them to fly where humans or alternative technologies cannot reach $^{45}$. That is in addition to their ability to take photos and videos from different angles ${ }^{46}$, and to stay aloft undetected ${ }^{47}$. They may also carry thermal cameras capable of capturing objects behind walls ${ }^{45}$. Nonetheless, drones are being misused to spy on residential and private spaces, raising privacy concerns among the public $^{48}$. 
Drones, however, are deficient technically: they are still unequipped with a failure mode or sense-and-avoid systems $^{46}$, which makes them vulnerable to weather conditions and to accidents with commercial aircraft in the airspace. Research assures the importance of integrating such systems to ensure safe landing in case of emergencies (e.g. power cut-off, flight instability, etc.) and to avoid accidents ${ }^{48}$. However, accidents up till the moment are unavoidable. There have been various incidents over the past few years ${ }^{49-53}$. In addition to the technical deficiency, these accidents are causing safety concerns among the public and civil authorities.

Thus, visitors, as well as the management, of the national parks are, by far, expected to have similar concerns. Accordingly, concessionaires are advised to implement measures that eradicate the causes of these concerns for the business to be successful. Such measures include (1) renting only high standard drones; (2) ensuring the pilots are licensed and aware of the ethical and technical issues associated with drone flight; and, recording renters' information for accountability reasons. Additional measures include identifying anticipated hazards; investigating pilots' flight history ${ }^{60}$; and assessing the drone's technical capabilities against reliability measures before flying into the airspace ${ }^{48}$.

\section{Two Drone Concession models for u.s. national parks}

There are several potential scenarios for the commercial use of civil drone within U.S. national parks. Two examples that might be typical after drones were allowed in national parks are presented here. The first is suitable for high visitation scenic areas inside national parks, while the second is appropriate for average recreational activities.

\subsection{Scenario One: Tethered Blimp ${ }^{1}$ Model at a Scenic Overlook}

A concessionaire is licensed to operate a small tethered blimp concession near a scenic overlook of a spectacular waterfall inside a national park. The concession is located away from where it might impact most scenic photo opportunities; yet close enough to provide a grandiose view of the famous location from the air.

\footnotetext{
${ }^{1}$ A blimp or lighter-than-air drone is one of three other types: fixedwing, rotary, and hybrid.
}

Blimps are capable of staying still and aloft for years ${ }^{54}$ and of providing a panoramic view in various directions with much convenience. With the use of latest photo or video editing technologies the concession may provide the park visitors with outstanding memories. Blimps may be of dual-purpose and provide visitors with free Wi-Fi connection $^{35}$ allowing them to make use of mobile phones or other gadgets. Visitors, after registration, are provided with login information and may enjoy having their own selfies and videos. This does not constitute a conflict of interest with the concessionaire(s) who provide a more advanced photo/video editing services.

The concession may install different types of payloads on the blimp such as first-person view cameras which provide the photo/video shooter with current view and location of the visitors ${ }^{55}$. The captures are simultaneously downloaded onto the computer at the concession counter or are uploaded to their webpage. The customer reviews several versions of the photos or videos and chooses their preferable one(s), which may be then downloaded onto their cell phone, a USB or forwarded to an email address. It is noteworthy that concessionaires shall set up reasonable charges for the services provided, despite using advanced editing techniques. Visitors who find fees exaggerated may turn over to other options such as using their own recording devices.

Blimps, are lighter than air aircraft, and then do not pose safety risks on visitors. Being tethered also assures that their fall, if any, will be in a controlled space less likely to harm individuals or property. Accordingly, their use should be of no concern to both visitors and the park's management. Concessionaires should be rather concerned about blimps' setup fees which are relatively expensive [e.g. each blimp may cost on average $\$ 5,000$, other than other overhead costs] compared to other drone types $^{56}$. Thus, this concession scenario is limited to those who can afford a big sum to kick off a business. Despite the concession may occupy only a small space, but is not considered a small business.

\subsection{Scenario Two: Rotary Aircraft on a rafting trip through the Grand Canyon}

A concession is licensed to rent out rotary drones with a follow-me technology to both private and commercial river rafting groups traveling through the Grand Canyon. The drone is programmed to fly no higher than $30 \mathrm{ft}$., and stay within $10 \mathrm{ft}$. of the raft's homing device. 
Multiple batteries are provided as part of the rental package so the drone can be used frequently during the trip. Drones equipped with the 'follow-me' technology, are novel and are quickly becoming popular. Several firms are producing and releasing these drones ${ }^{57}$ with reasonable prices ${ }^{58,59}$ [e.g. \$999] which is making them available and affordable for virtually anyone interested in trip recording.

Back to the current scenario, a group of visitors is required to pay for the rental fee which depends on the rafting trip time, and which includes purchasing drone insurance to compensate the concessionaire in case of loss or damage of the device. Additionally, they may rent spare batteries relative to the trip length. They may also be provided with spare propellers and a small toolkit in case of minor accidents so recording opportunities will not be lost during a 'not-everyday' experience.

River rafting experiences by nature carry some safety risks, which are not related to the tiny follow-me drone which even in case of fall will be of negligible harm. In fact, drones on a rafting trip may be useful in providing the group's coordinates to the concessionaire or emergency response team in case of major accidents. Neither privacy concerns are relevant on a rafting trip as the drone will be recording only the group's activity. To the concessionaire business setup fees will be relatively low due to the cheap drone price. However, they are required to ensure the visitors' safety by establishing constant communication with a team-leader and a dual connection to the drone to keep them updated with the coordinates. The concessionaire is also required to apply safety objectives and explain them to the team-leader and other group members. Every group member signs a form acknowledging that they understand and agree to abide by the terms of the rental contract.

\section{Conclusion}

This research, motivated by the several socioeconomic benefits of civil drones, has answered the question 'how can concession models within national parks employ drones to generate profit?'. The paper discussed the concept of concessions as stated by the U.S. national parks system, and associated contracts and regulations. Additionally, the paper briefly discussed the concerns of various stakeholders including the visitors and the national park's management.
In this paper, of practical nature, we propose two examples of concessions which can attract more visitors, and accordingly generate more profit for both the park and the concession(s). In the first example, we proposed a concession which provides advanced editing services for panoramic photos and videos taken from tethered blimps, in addition to free Internet connections. We have discussed that the blimps will not pose safety risks, however will require a big amount of money. In the second example, we proposed a concession that will rent follow-me rotary drones for groups going on rafting trips. We have discussed that the idea does not pose safety risks on the group of rafters but the rafting trip itself. Contrarily, we have shown that the use of drones on the trip may be helpful in providing the group's coordinates in case of major accidents, and that this concession idea is affordable and relatively incurs low costs on the concessionaires.

The paper contributes to the increase in commercial drone movement specifically in the tourism sector. The proposed ideas may boost the profits generated in national parks, and consequently the overall revenues of the tourism sector. When this idea is proliferated and variated, it will increase tourism activities and subsequently the revenues and even national GDP. Such businesses will also create jobs and contribute to alleviating the impact of economic crisis.

The paper also contributes to the growing body of knowledge on drone application in various fields. However, it doesn't paper does not propose a conceptual model because of the practical nature of the study. Future research may attempt to address the issue from a theoretical perspective employing relevant existing technology adoption theory. The study proposes only two examples of concessions in national parks. However, drones' capabilities make their use extendable to several more concession models which may be addressed by future research. Finally, this research has considered concessions in U.S. national parks only. Future research may replicate or extend this study in different contexts.

\section{Acknowledgment}

We would like to thank the anonymous reviewers for their constructive feedback which helped deliver this paper in its best form. 


\section{References}

[1] Valavanis, K.P. and Vachtsevanos, G.J. (2015) Handbook of Unmanned Aerial Vehicles. Springer Science + Business Media, Dordrecht, 1-3022.

[2] NPS, "History", National Park Service, 2015, http://www.nps.gov/aboutus/history.htm

[3] Temple University, "ProRanger program", Temple University, 2014 , http://www.temple.edu/provost/universitycollege/proranger/about/index.html

[4] NPS, "Frequently asked questions", National Park Service, 2015, http://www.nps.gov/faqs.htm

[5] H. H. Chouinard, "Auctions with and without the right of first refusal and national park service concession contracts", American Agriculture Economics Association,pp. 1083-1088, 2005.

[6] S. Rogers and J. Hunter, "Guidelines for commercial activity and concession sales within Portland Parks", Portland Parks and Recreation, pp. 1-14, 2011.

[7] NPS, "About us", National Park Service, 2015, http://www.nps.gov/aboutus/index.htm.

[8] NPS, "Mission", National Park Service, 2015, http://www.nps.gov/aboutus/mission.htm

[9] United States Senate, "National park service concessions program: hearing before the subcommittee on national parks of the committee on energy and natural resources", Authenticated U.S. Government Information, pp. i-58, 2004.

[10] NPS Advisory Board, "Revisiting Leopold: resource stewardship in the National Parks", NPS Advisory Board, pp. i-23, 2012.

[11] A.R. Bell, R.L. Riolo, J.M. Doremus, D.G. Brown, T.P. Lyon, J.Vandermeer and A. Agrawal, "Fragmenting forests: the double edge of effective forest monitoring", Environmental Science and Policy, Vol 16, pp. 20-30, 2012.

[12] Headwaters Economics, "Economic impact of National Park Service units: understanding the effect of visitation, spending, and other economic values on nearby communities", Headwaters Economics, 2015.

[13] S. Marimon and J. Yocum, "Comparative Analysis of Concession Operations", National Park Service Commercial Services Program, pp. 1-30, 2009.

[14] C.C. Thomas, C. Huber and L. Koontz, "2013 National park visitor spending effects: economic contributions to local communities, states, and the nation", pp. 1-52, 2014.

[15] U.S. Travel Association, "2013 Travel Economic Impact Overview”, U.S. Travel Association, pp.1-2, 2014.

[16] Investopedia, "Concession agreement", Investopedia, 2015.

http://www.investopedia.com/terms/c/concessionagreem ent.asp

[17] M. Wyman, J.R. Barborak, N. Inamdar and T. Stein, "Best practices for tourism concessions in protected areas: a review of the field", Forests, Vol 2, pp. 913-928, 2011.

[18] P. Fearnhead, "Commercial tourism concessions: a means of generating income for south african national parks", Fifth World Parks Congress, pp. 1-9, 2003.

[19] UNDP, "Tourism concessions in protected natural areas: guidelines for managers", UNDP, pp. i-302, 2014.

[20] National Trust, "Historic leasing in the national park system: preserving history through effective partnerships", National Trust for Historic Preservation, pp. 1-53, 2013.

[21] NPS, "Management policies 2006", National Park Service, pp. i-180, 2006.

[22] NPS, "National park omnibus management act of 1998", National Park Service, pp. 1-18, 1998.

[23] National Park Hospitality Association and U.S. Department of Interior, "Certiorari to the united states court of appeals for the district of columbia circuit", pp. 803-821, 2002.

[24] NPS, "Doing business with national park service concession program", pp. 1-20, 2007.

[25] DOI and NPS, "Business opportunity", Department of Interior and National Park Service, pp. 1-8, 2014.

[26] T. Quinn, "Public lands and private recreation enterprise: policy issues from a historical perspective", U.S. Department of Agriculture, pp. i-33, 2002.

[27] DOI and NPS, "Federal Register", Vol 79, pp. 5826158263, 2014.

[28] D. Mirk and H. Hlavacs, "Using drones for virtual tourism”, INTETAIN, LNICST 136, pp. 144-147, 2014.

[29] L. King, "Will drones revolutionise ecotourism?", Journal of Ecotourism, Vol 13, pp. 85-92, 2014.

[30] M. Berman, "National Park Service bans drone use in all national parks", The Washington Post, 2014.

[31] NPS, "National Park Service press release", National Park Service, 2014.

[32] M.M. Ahlers, "National Park Service bans drones over safety, noise worries", CNN, 2014.

[33] Russia Today, "Man who crashed drone into Yellowstone hot spring sentenced to probation and banned from national park", Russia Today, 2014.

[34] NPS, "Policy related regulations", National Park Service, 2015. http:/home.nps.gov/applications/npspolicy/getregs.cfm

[35] LeMieux, J. (2014) Drone: DRONE Dictionary. Unmanned Vehicle University, Phoenix.

[36] Chandran, Nyshka. (2016). Coming soon: Drone food deliveries in Singapore. Retrieved from: http://www.cnbc.com/2016/03/16/foodpanda-testsdrone-deliveries-in-singapore.html

[37] Hern, Alex. (2014). DHL launches first commercial drone 'parcelcopter' delivery service. Retrieved from: https://www.theguardian.com/technology/2014/sep/25/ge rman-dhl-launches-first-commercial-drone-deliveryservice

[38] Chhabra, Esha. (2015). Drones for Good: Projects from Around the World on How Drones Can Help Us. 
Retrieved from: https://www.forbes.com/sites/ eshachhabra/2015/02/27/drones-for-good-projects-fromaround-the-world-on-how-drones-can-help-us/ \#212a9b2d5d33

[39] Prigg, Mark. (2014). The ambulance drone that could save your life: Flying defibrillator can reach speeds of 60mph. Retrieved from: http://www.dailymail.co.uk/ sciencetech/article-2811851/The-ambulance-drone-savelife-Flying-defibrillator-reach-speeds-60mph.html \#ixzz4aiNreZib

[40] Gibbens, D. (2014) Editorial Integrating UAS into the Oil and Gas Industry.

[41] Guiraud, M. and Nachescu, M.-L. (2012) Drones as a Tool of Sustainable Development-Consequences of Their Usage and New Forms of Risk Management. Economic and Environmental Studies, 12, 467-479.

[42] Jenkins, D. and Vasigh, B. (2013) The Economic Impact of Unmanned Aircraft Systems Integration in the United States. 1-40.

[43] Volovelsky, U. (2014) Civilian Uses of Unmanned Aerial Vehicles and the Threat to the Right to PrivacyAn Israeli Case Study. Computer Law \& Security Review, 30, 306-320.

[44] EU Business (2014) Remotely Piloted Aviation Systems, or Drones. Retrieved from: http://www.eubusiness.com/ topics/transport/drones/?searchterm=droneeconomy

[45] Galliot, J. C. (2012). Uninhabited systems in the civilian realm: Some ethical concerns [Commentary]. IEEE Technology and Society Magazine, 31(2), 13-16. http://doi.org/10.1109/MTS.2012.2202017

[46] Clarke, R. (2014a). Understanding the drone epidemic. Computer Law and Security Review, 30(3), 230-246. http://doi.org/10.1016/j.clsr.2014.03.002

[47] Calo, R. M. (2014). Robots and Privacy. In P. Lin, G. Bekey, \& K. Abney (Eds.), Robot Ethics: The Ethical and Social Implications of Robotics. MIT Press.

[48] Elias, B. (2012). Pilotless Drones: Background and Considerations for Congress Regarding Unmanned Aircraft Operations in the National Airspace System. Congressional Research Service, $1-24$. Retrieved from http://www.fas.org/sgp/crs/natsec/R42718.pdf
[49] BBC. (2015). Toddler's eyeball sliced in half by drone propeller. Retrieved from http://www.bbc.com/news/ukengland-hereford-worcester-34936739

[50] BBC. (2011). Police drone crashes into River Mersey. Retrieved from http://www.bbc.com/news/uk-englandmerseyside-15520279

[51] Bloomberg. (2015). Google's Solar-Fueled Cyber Drone Crashes in New Mexico Test. Retrieved from http://www.bloomberg.com/news/articles/2015-0529/google-s-solar-fueled-cyber-drone-crashes-duringnew-mexico-test

[52] Business Insider. (2013). Video of Drone Crashing Into Cargo Plane In Afghanistan Raises Concern Over German DRONE Safety. Business Insider. Retrieved from: http://www.businessinsider.com/drone-crashraises-concern-over-safety-2013-7?IR=T

[53] Sydney Morning Herald. (2014). "River of blood" after drone "hits" Australian Athlete. Retrieved from http://www.smh.com.au/technology/technologynews/river-of-blood-after-drone-hits-australian-athlete20140407-zqruh.html

[54] Sebbane, Yasmina Bestaoui. (2012). Lighter than Air Robots. First. Dordrecht: Springer Science + Business Media. doi:10.1007/978-94-007-2663-5.

[55] Smolyanskiy, Nikolai and Mar Gonzalez- Franco. (2017). 'Stereoscopic First Person View System for Drone Navigation'. Frontiers in Robotics and AI 4(1): pp. 1-10. doi: 10.3389/frobt.2017.00011

[56] California Blimps. (2017). 'Blimps Prices and Specifications'. Retrieved from: http://californiablimps. com/blimp-prices.htm

[57] Chamata, J.E. (2017). Convergence of the Unmanned Aerial Industry. Theoretical Economics Letters, 7,175186. https://doi.org/10.4236/tel.2017.72015

[58] Hexo +. (2016). Hexo + Homepage. https://hexoplus.com/

[59] 3DR. (2016). 3DR Homepage. https://3dr.com/solodrone/

[60] Clothier, Reece, and Rodney Walker. (2006). "Determination and Evaluation of UAV Safety Objectives." 21st International Unmanned Air Vehicle Systems Conference 2006: 18.1-18.16. 